\title{
A MODEL OF OLDER WORKERS' INTENTIONS TO CONTINUE WORKING
}

\section{Introduction}

There is a lack of knowledge about the factors affecting older workers' intentions to continue in employment. At a general level, this is significant because Australia is similar to many OECD countries in that we face an ageing population and a shortage of skilled labour (Productivity Commission, 2006). Further, ageing tends to cause a decline in participation rates because, as people grow older, they tend to participate less in the labour force, by either retiring or leaving the workforce well before their sixties (Australian Bureau of Statistics, 2005), and age discrimination still exists (Encel and Studencki, 2004; Branine and Glover, 1997; Glover and Branine, 1997; Lyon and Pollard, 1997).

However, there is relatively little written about the factors influencing older workers' intentions to continue working, and there is a lack of a model or framework for examining and explaining why people choose to stay at work (Lee and Mitchell, 1994). Further, few

organisations have implemented strategies specifically aimed at older worker retention (Schramm, 2006). One reason may be the lack of knowledge about appropriate strategies for older workers.

Therefore, this paper proposes an extension to parts of the Meaning of Working (MOW) theoretical model (MOW International Research Team, 1987; Westwood and Lok, 2003) to explain older workers' intentions to continue paid working and then develops and tests a scale for measuring the impact of work-related factors upon their intentions. Workrelated factors associated with the meaning of working, which affect older workers' intentions to continue paid working (OWICW), are therefore examined. By identifying new influences, this paper is able to extend the MOW model to explain the work-related factors influencing OWICW and consequently, suggest older worker retention strategies for organisations and HRM.

\section{Conceptual development}


Working is usually considered to be of relatively high importance when compared with meaning in other areas in a person's life (England, 1991). Working is also generally known to be more important than leisure, community and religion and was found in several studies to be ranked second only to family (Harpaz, 1999; MOW International Research Team, 1987). Work is apparently so important to some individuals that they are willing to work even though they have enough money to maintain their lifestyle without it. Others would prefer to stop working as soon as feasible. For some individuals, it seems, life and work are tied inextricably together and for others, work and other aspects of their life could not be further apart. Investigation is therefore needed into whether older workers want to continue working for reasons other than the often-cited economic reason and what factors might influence such intentions.

To begin such investigations, this paper uses a MOW framework (MOW International Research Team (MOWIRT), (1987). However, only limited development of alternatives or extensions to the model has since occurred, except for example, Westwood and Leung (1996) and Westwood and Lok (2003), who explored the impact of national cultural factors upon the model and extended the model to include the influence of the organisation (see Figure 1 for their model, adapted to include new highlighted areas for testing). Research has not explored the meaning of working for older workers. Within the current context of predicted labour shortfalls in most OECD countries, due to ageing workforces, it is time to tailor or extend the MOW model to account for older workers. The organisational factors which may impact upon OWICW are crucial for management to understand, to maximise the retention of valued older workers. Such a model would help explain why older workers may choose to continue in, or leave, employment and how organisations can affect such choices. Such factors have not been part of the previous meaning of working investigations, nor incorporated within a theoretical model.

[Figure 1 about here] 
This paper contends that the consequences of 'subjective expectations about future working situations' are insufficiently defined and detailed, and these consequences of the meaning of working need to be better conceptualised and operationalised within a MOW model for older workers. By identifying the organisational factors which impact upon older workers' intentions to continue working within the MOW framework, this paper intends to extend part of that model by making transparent the subjective set of consequences. Diagrammatically, this will be achieved by exploring the shaded areas in Figure 1. Because the meanings of working are culturally bound (MOWIRT, 1987), it is necessary to limit the research to one culture or country, and the culture/country chosen for this research was Australia.

\section{Literature Review}

Previous research has identified factors as relevant to the decision to retire. Some of these factors have negative influences on the decision to retire, such as attachment to, or passion for, work (Barnes, et al., 2004; Patrickson and Ranzijn, 2004), whereas others have positive influences on the retirement decision, such as outside interests (Humphrey, et al., 2003; Phillipson and Smith, 2005), caring responsibilities (Evandrou and Glaser, 2004; Loretto, et al., 2005) and negative factors at work (Blekesaune and Solem, 2005). However, the majority of previous research has focused on the factors affecting the decision to retire, not the intention to continue working.

There has been little research looking at the concerns of the combined areas of work meanings and age in Australia; even less using qualitative research methods (except for Probert and MacDonald, 1996; Shacklock, 2006; 2008; Shacklock, et al., 2007). Overall, Probert and MacDonald found that paid work is important to older people's sense of selfidentity, while Shacklock (2008) suggested the following factors influence older workers’ intentions to continue in employment:

(a) Health of self and family 
(b) Finances

(c) Attachment to work

(d) Importance of working to the individual,

(e) Perception of personal autonomy at work,

(f) Interpersonal relationships at work

(g) Flexible work arrangements,

(h) Interests outside of work, and

(i) Management and organisational factors, such as supervision, bureaucracy and work environment.

However, it is unclear whether these factors are generalisable to the wider population of employees aged 50 years and over. This is an important question to examine because of the growing labour shortages evident in most OECD countries today. Policy makers, academics and practitioners alike need to rethink how present HRM and management strategies, policies and practices affect the retention of older workers. Part of the rethinking process must involve the development of a viable and workable model from which to begin analysis of this important issue.

Similarly using a MOW theoretical framework, Shacklock (2006; 2008) explored the range of factors that might influence older workers' intentions, and that research has been chosen as the basis for this study. It is necessary to quantitatively operationalise the factors identified in that research into a conceptual framework comprising specific variables and develop scales that test the significance of each of these variables. The purpose of this paper is therefore to present evidence supporting the development and validation of a conceptual framework for operationalising OWICW comprising work-related factors, thereby extending part of the MOW model to include older workers.

The first two factors discussed below are the health and financial situations of older workers. The factors of personal and family health, plus financial circumstances, are 
important because they impact to a large degree upon individuals' choices regarding their intentions to continue working - in certain circumstances there may be limited or no choices. It is only when health allows that one has a choice to continue working, and only when financial circumstances allow that one has a choice to reduce or stop working, or retire. Both of these factors have been frequently identified in previous research and therefore will not be re-investigated here, as this paper specifically investigates new or under-researched organisational factors tested within the context of older workers. Further, re-testing acknowledged influential factors would be difficult to contain within the size limits of this paper.

\section{3a. Health of self and family}

According to a review of the retirement literature, health has a significant impact upon a person's decision to retire (American Association of Retired Persons, 2005; Australian Bureau of Statistics, 2006; Humphrey, et al., 2003; Phillipson and Smith, 2005). Other important health factors in the decision to retire include factors that may inhibit a person's ability to carry out the work, such as physical limitations and health problems of the worker, as well as the health of the worker's partner (Talaga and Beehr, 1995).

\section{3b. Finances}

Individuals' financial situations include issues of savings (both personal and superannuation), housing ownership, other investments, dependence of others (children, elderly parents or sick relatives), expected income stream from combined pension and superannuation and adequacy of health insurance (Department of the Treasury, 2004b; Patrickson and Ranzijn, 2004). If finances are healthy, the decision to retire may be possible at any age or stage. On the contrary, if finances are unhealthy, the option to retire may not be realistic at a particular point in time. Financial circumstances have been found by many researchers to be significant in the decision to retire (Department of the Treasury, 2004a; 
Jackson, et al., 2006; Phillipson, 2004) and especially for separated or divorced women (Smeaton and McKay, 2003).

\section{3c Attachment to work}

The literature confirms the role of work "passion" or attachment to work in the desire to continue working (Barnes, et al., 2004; Patrickson and Ranzijn 2004). Attachment to work is typically related to the content of the work or job itself, as for a doctor who is committed to healing and the profession as a whole. Positive views about work have been found to influence well-being and identity, encouraging older people to consider the extension to their working lives into later ages. For example, in the retirement decision literature, psychological factors such as reduced commitment and job satisfaction and dissatisfaction with career attainment were influential (Ekert and DeViney 1993), as well as the negative perception of changing from work to retirement when strong attachments to jobs were evident (Barnes and Parry 2003). Attachment to work was found to affect people’s retirement decisions (Barnes, et al., 2004), including satisfaction with the current job (Anderson, et al, 2002) and the motivation to work (Patrickson and Ranzijn, 2004). It appears that little or no investigation has been undertaken about any relationship between work attachment and the intention to continue working. Additionally, many of the above findings have been derived post hoc by investigating labour market trends and other data sets. The hypothesis used to test this premise is:

H1: There is a positive relationship between older workers' attachment to work and their intentions to continue working.

\section{3d. Importance of work to the individual}

Positive views about work were found to influence well-being and identity, encouraging older people to consider the extension of their working lives into later ages. Similarly, but within the retirement conceptual frame, Ekert and DeViney (1993) found psychological factors such as reduced commitment and job satisfaction, dissatisfaction with 
career attainment, and anxieties about leaving the workplace were positive influences on the retirement decision. Further, Barnes and Parry (2003) found negative perceptions of changing from work to retirement for those who considered their jobs to be important, and therefore typically delaying retirement. Anderson, et al. (2002) used a large Australian multi-university survey to identify that academic staff still found attractions to the academic way of life. In summary, a review of the literature suggests that the importance of work to the individual may be an important variable affecting OWICW. It therefore should be tested within the general population and the hypothesis is:

H2: There is a positive relationship between the importance of working to older workers and their intentions to continue working.

\section{3e Interpersonal relationships at work}

The opportunity to interact with others while at work has been found to be attractive to older workers, with retirees reporting they missed the relationships they had had while working (Shacklock, 2006). Further, social relationship at work was found to be an important factor in working, particularly later in life (Choo, 1999), and after the traditional age of retirement (Smeaton and McKay, 2003). However, the impact of relationships at work upon the intention to continue working has not been tested. The following hypothesis is therefore proposed:

H3: There is a positive relationship between older workers' interpersonal relationships at work and their intentions to continue working.

\section{3f. Perception of personal autonomy at work}

One factor that may affect employees' decisions to retire is their level of autonomy in the decision-making at work (Friedmann and Havighurst, 1977; Phillipson and Smith, 2005). Employees' autonomy in the workplace refers to their ability to make decisions about how and when to undertake workplace tasks (De Jonge, 1995); however, the issue is as relevant to employees considering whether to continue working. As evidence of such a relationship, 
early retirement (the opposite of continuing to work) was related to low levels of autonomy in job tasks among males in Norway (Blekesaune and Solem, 2005). This finding was supported within the Australian context by Shacklock and Brunetto (2005), who found that perceived autonomy in the workplace was a negative influence on the decision to retire. Whilst Patrickson and Ranzijn (2004) argued that individuals make the decision to retire based on their 'bounded choices' when considering their financial position and health situation, it seems likely that other factors (such as their perception of autonomy) may affect their decicion. To test this premise, the following hypothesis is proposed:

H4: There is a positive relationship between older workers' perceptions of personal autonomy at work and their intentions to continue working.

\section{3g. Flexible work arrangements}

The greater participation rate of women in the labour force over recent times (ABS, 2006) has driven the demand for improved balance between the demands of work with the obligations of family and home. Gallie and White (1993) found, as did MOWIRT (1987), that continued interest in working without the financial need to do so was influenced by the flexibility of working arrangements (continuing to work but under different conditions). In particular, there is some consensus that older workers want flexibility in their work arrangements if they are to continue working (Arrowsmith and McGoldrick 1997; Jackson, et al. 2006; Productivity Commission 2005). Patrickson and Ranzijn (2004) argued that offering flexible work to older workers close to their retirement decision was viewed by them as an attractive option. In overseas research, older UK professionals found different forms of working (especially freelancing, consulting and self-employment) to be attractive employment options (Platman, 2004) that may influence their intentions to continue working longer. Overall, flexible work arrangements and their impact upon older workers and their intentions to continue working remain under-researched. Therefore the next hypothesis is: 
H5: There is a positive relationship between flexible work arrangements and older workers' intentions to continue working.

\section{3h. Interests outside of work}

One of the strongest findings from past research within the retirement literature is that a majority (83\%) of those who intended to retire early reported they would do so in order to “enjoy life while they were still fit and young” (Phillipson and Smith, 2005: 28). In that research, a new direction in their lives was cited as one of the main reasons, as well as the desire to spend time with a partner. Similarly, Laslett (1989) argued that retirement allows more time for generally pursuing life goals, and Ginn and Arber (2005) found that older people were more likely to seek certain characteristics about jobs they might choose, including less manual labour and more quality-adding to their lives. Further, the MOWIRT (1987) found that there were several interests outside of work that affected individual's meaning of working, including: family, friends, spiritual development, community, hobbies, and leisure. However, overall, research has not identified how interests outside of work affect the intentions of older workers to continue working. Therefore, the hypothesis is:

H6: There is a negative relationship between older workers' interests outside of work and their intentions to continue working.

\section{3i. Management and organisational factors, such as supervision, bureaucracy and work}

\section{environment}

Organisational policies have traditionally been of little support in encouraging employees to stay working beyond the traditional age of retirement. In particular, Drucker (2001) criticised human resource managers for not supporting older workers and continuing to favour younger people. The experience of older workers is that the majority retired for reasons beyond their control (81 percent of men and 64 percent of women), with the majority of these citing “significant employment problems” prior to their retirement (Sheen 1999: 8). These reasons, she argued, may have been related to age victimisation in the workplace, and 
the forceful use of casualisation of jobs. Since age discrimination still occurs in Australia (Encel and Studencki 2004) and other major developed countries (AARP, 2007) such arguments are likely to be valid. Further, Platman (2004) found that the type and characteristics of work and the working environment was important to older workers when considering their working futures. To examine the significance of management and organisational factors on older workers' intentons to continue working, the following hypothesis was developed:

H7: There is a negative relationship between older workers' perceptions of poor management and organisational factors, and their intentions to continue working.

\section{Conceptual framework}

This paper proposes the notion of “older workers' intentions to continue paid working” (OWICW) and tests an extended MOW model of the impact of work-related factors upon such intentions. Figure 1 illustrates the relationships amongst the variables (highlighted). The specific variables to be tested are: 1) attachment to work, (2) importance of working to the individual, (3) interpersonal relationships at work, (4) perception of personal autonomy at work, (5) flexible work arrangements, (6) interests outside of work, and (7) management and organisational factors, (such as supervision, bureaucracy and work environment) (see the highlighted box in Figure 1). The inclusion of each factor in the model was informed by the measure validity for each as reported in empirical research. Table 1 details the origin of the different factors under examination.

\section{Table 1}

Constructs, variables and test instruments

\begin{tabular}{|l|l|l|}
\hline \multicolumn{1}{|c|}{ Construct } & \multicolumn{1}{|c|}{$\begin{array}{c}\text { Variable (in alpha } \\
\text { order) }\end{array}$} & \multicolumn{1}{c|}{$\begin{array}{c}\text { Test instruments } \\
\text { (modified for older workers) }\end{array}$} \\
\hline WORK- & Autonomy at work & $\begin{array}{l}\text { Questions drawn from Meaning of Working } \\
\text { International Research Team (MOWIRT) (1987). }\end{array}$ \\
FELATED & & $\begin{array}{l}\text { For example, rating the statement 'The freedom to } \\
\text { determine how I do my work would affect my } \\
\text { intention to continue paid work'. }\end{array}$ \\
\hline
\end{tabular}




\begin{tabular}{|c|c|c|}
\hline & Attachment to work & $\begin{array}{l}\text { Attachment to work was measured by an } \\
\text { instrument validated by the MOWIRT (1987). } \\
\text { Questions included 'People in my area of work } \\
\text { have a real "calling" to their work'. }\end{array}$ \\
\hline & $\begin{array}{l}\text { Interpersonal } \\
\text { relationships at work }\end{array}$ & $\begin{array}{l}\text { Questions were drawn from Rubin, Perse and } \\
\text { Barbato (1988), for example 'My intention to } \\
\text { continue paid work would be affected by the } \\
\text { feelings of importance I get from dealing with } \\
\text { people'. }\end{array}$ \\
\hline & $\begin{array}{l}\text { Flexible work } \\
\text { arrangements }\end{array}$ & $\begin{array}{l}\text { Questions were asked about the opportunity to } \\
\text { work casually, to work part-time and flexibility of } \\
\text { working hours generally, from Shacklock (2008). } \\
\text { For example, rating the statement 'My intention } \\
\text { to continue paid work is affected by the } \\
\text { opportunity to work casually (to work when I feel } \\
\text { like it or when I need to)'. }\end{array}$ \\
\hline & $\begin{array}{l}\text { Management and } \\
\text { organisational factors }\end{array}$ & $\begin{array}{l}\text { Ask questions about supervision, bureaucracy } \\
\text { levels and motivators at work, as found by } \\
\text { Shacklock (2008). For example, rating the } \\
\text { statement 'My intention to continue paid work } \\
\text { would be affected by the level of bureaucracy /red } \\
\text { tape at work'. }\end{array}$ \\
\hline & $\begin{array}{l}\text { Importance of working } \\
\text { to the individual }\end{array}$ & $\begin{array}{l}\text { Questions drawn from MOWIRT (1987). For } \\
\text { example, rating the statement 'Working is the } \\
\text { most important thing in my life' }\end{array}$ \\
\hline & Interest outside of work & $\begin{array}{l}\text { Questions drawn from MOWIRT (1987). For } \\
\text { example, rating the statement 'My intention to } \\
\text { continue paid work would be affected by my } \\
\text { hobbies'. }\end{array}$ \\
\hline & Work area (control) & $\begin{array}{l}\text { This is the element or unit of the organisation in } \\
\text { which the respondent works. }\end{array}$ \\
\hline $\begin{array}{l}\text { DEPENDENT } \\
\text { VARIABLE }\end{array}$ & $\begin{array}{l}\text { Intention to continue } \\
\text { working }\end{array}$ & $\begin{array}{l}\text { Question from Shacklock (2008), rating the } \\
\text { statement 'I want to continue paid work'. }\end{array}$ \\
\hline
\end{tabular}

\section{Methods}

The paper uses a cross-sectional, survey-based; self-report strategy to gather data so as to test a scale for measuring the impact of work-related factors on older workers' intentions to continue working. Whilst there has been criticism about using a self-report data gathering method (because of the problems of common method variance and same source bias etc), it is probable that the best way of gauging older workers' intentions to continue working is to ask them. 


\subsection{Measures}

A questionnaire was developed using a 7-point Likert-type scale ranging from 1 (strongly disagree with the statement) to 7 (strongly agree) for each of 41 statements. The statements were based on each of the seven variables and sought responses in relation to the impact each would have on the respondent's intention to continue working. In order to compare these factors for different groups, the scores of all questions in that factor were averaged for each respondent, providing a consolidated measure for that factor; for example, overall importance of working to the individual.

\subsection{Testing the Measurement Model}

As stated, each of the independent work-related factors expected to influence older workers' intentions to continue paid work was examined by developing several questions relating to that factor. A pilot study was then undertaken and data was collected from ten randomly selected older workers. This was followed by a test for the reliability of each measure using alpha scores. Several measures had to be modified to improve their alpha score (see Table 2 for full sample scores). Specifically, one question was deleted from each of: "flexible work arrangements”, “management and organisational factors at work”, and “interests outside of work". Additionally, an extra question concerning physical capacity was added to the issue of "management and organisational factors". Finally, a new question concerning the impact of a spouse/partner on intentions to continue working was added to “interests outside of work" as the preliminary pilot data suggested this could be an important factor.

Table 2

Questions removed to improve validity of the variables

\begin{tabular}{|l|c|c|c|c|c|}
\hline \multicolumn{1}{|c|}{ Variable } & $\begin{array}{c}\text { Orig } \\
\text { No. } \\
\text { Items }\end{array}$ & $\begin{array}{c}\text { Orig } \\
\text { Cronbach's } \\
\text { Alpha } \\
\text { (pilot study) }\end{array}$ & $\begin{array}{c}\text { No. } \\
\text { Revised } \\
\text { Items }\end{array}$ & $\begin{array}{c}\text { Revised } \\
\text { Cronbach's } \\
\text { Alpha } \\
\text { full sample) }\end{array}$ & Source and Notes \\
\hline $\begin{array}{l}\text { Attachment to } \\
\text { work }\end{array}$ & 3 & .76 & 3 & .76 & \\
\hline Importance of & 3 & .69 & 3 & .69 & \\
\hline
\end{tabular}




\begin{tabular}{|l|c|c|c|c|l|}
\hline $\begin{array}{l}\text { working in your } \\
\text { life }\end{array}$ & . & & & & \\
\hline $\begin{array}{l}\text { Interpersonal } \\
\text { Relationships }\end{array}$ & 6 & .811 & 6 & .811 & \\
\hline $\begin{array}{l}\text { Personal } \\
\text { autonomy at } \\
\text { work }\end{array}$ & 5 & .869 & 5 & .869 & \\
\hline $\begin{array}{l}\text { Flexible working } \\
\text { arrangements }\end{array}$ & 4 & $\begin{array}{c}.275 \\
\text { Need to } \\
\text { delete item 3, } \\
\text { then increases } \\
\text { to .852) }\end{array}$ & 3 & .89 & Delete item 3 \\
\hline $\begin{array}{l}\text { Management and } \\
\text { organisational } \\
\text { factors }\end{array}$ & 4 & .572 & 4 & .76 & $\begin{array}{l}\text { Delete item 3. Added } \\
\text { Physical capacity } \\
\text { question. }\end{array}$ \\
\hline $\begin{array}{l}\text { Interests outside } \\
\text { of work }\end{array}$ & 7 & -0.011 & 7 & .85 & $\begin{array}{l}\text { Delete item 6. } \\
\text { Add new item } \\
\text { "spouse/partner". } \\
\text { Changed all questions } \\
\text { to “my intention to } \\
\text { continue working is } \\
\text { affected by...”. }\end{array}$ \\
\hline
\end{tabular}

Using the threshold of 0.7 alpha score, all full sample measures except for "Importance of working to the individual” (alpha score of .69) had adequate reliability, according to Nunnally (1978). This measure was adopted from a validated test bank (MOWIRT, 1987), but it is new as a measure specifically for older workers' importance of working. Therefore it is argued that in this case it can be acceptable because, according to Nunnally (1978), a new measure within the range of .6 to .69 is often acceptable pending replication. This measure within the older worker context remains an area to address in future research.

\subsection{Pilot Study and sample}

A pilot study was undertaken using a convenience sample of ten older workers from a large public sector organisation located in the same region. The older workers were all aged 50 years or over and were all working, employed across a wide range of job types, and represented a range of skills, hierarchical levels, age differences (of 50 and older), and both genders. The characteristics of the sample were therefore representative of the main sample. 
Purposeful sampling underpins all sampling decisions (Yin, 1994). This research is focused on older workers in a large (over 3000 employees) public sector organisation so as to capture the largest potential sample as well as the widest range of older workers based on skills and occupation. The organisation has typical Australian public sector HRM policies with regard to age and the treatment of older (and younger) workers, including compliance with the Age Discrimination Act 2004, and in terms of recruitment and selection decisions, performance management outcomes, and training and development activities and opportunities. No specific financial policies exist for encouraging older workers to stay, nor to retire early. Respondents were sought from all employees aged 50 years and older because the USA Center for Aging and Work, Boston, defines “older workers" as those 50 years of age and older. The organisation identified that over 1000 employees met this minimum age criterion and sent a survey to all of these older workers by mail to their home address enclosing a covering letter encouraging support for the survey and confirming confidentiality. The anonymous survey typically took 24 minutes to complete and respondents returned it via the pre-paid envelope supplied that was addressed to the researchers.

\subsection{Factor Analysis}

The correlation matrix identified many correlations exceeding .3, indicating the matrix was suitable for factoring. The Bartlett's test for Sphericity was significant (Chisquare value $=5038.9922, \mathrm{p}<.001$. $\mathrm{df} 465)$ and the KMO measure of sampling adequacy was .84 - well above the .6 requirement. When Principal Axis Factoring was undertaken to extract the variables, seven factors had eigenvalues greater than one and $65.73 \%$ of the variance could be explained using these seven factors. The factor transformation matrix suggests a relatively high correlation between factors. 


\subsection{Quantitative component and analysis}

Surveys were distributed to 1012 older workers of a large organisation in SouthEastern Queensland. In response, 379 useable questionnaires were obtained. In each case, envelopes were left within designated areas for respondents to seal once the completed questionnaires were inserted and the sealed envelopes were then returned to the researchers.

Regression analysis was used to test the impact of attachment to work, importance of work, interpersonal relationships, perception of autonomy, flexible working arrangements, management and organisational factors and interests outside of work upon older workers' intentions to continue to paid work. The Statistical Package for the Social Sciences (SPSS), Version 12, was used to analyse the data. In particular, the analysis involved undertaking correlations (so as to determine whether significant relationships were evident between the variables) and regression procedures (to predict older workers' predisposition to continue working). These findings are detailed later in this paper.

\section{Results}

The overall response was 379 completed surveys, a response rate of 38\%. Of the 379 respondents, $67.3 \%$ were male and $31.9 \%$ female (see Table 3). Examination of age group showed the greatest number of respondents (47.9\%) were in the 50-54 years age group, followed by 55-59 (33.2\%), 60-64 (14.9\%), 65-69 (3.7\%) and 1 respondent was aged 70 years or over (see Table 3). In addition to identifying to which age group they belonged, respondents were also asked to provide their age in actual years, because it was felt that some respondents may object to providing their actual age, and thus age groups were sought first. The average age of all respondents who provided their actual age $(\mathrm{N}=344)$ was 55.29 years, with more people at the age of 50 years than at any other age.

Table 3

Demographics of Respondents

\begin{tabular}{l|c|c|c|} 
Males & Females & Employees & Percent \\
\hline
\end{tabular}




\begin{tabular}{|l|c|c|c|c|}
\hline & & & $\mathbf{( N = 3 7 9 )}$ & $\mathbf{( \% )}$ \\
\hline Gender & & & & \\
Male & 255 & & 255 & 67.3 \\
Female & & 121 & 121 & 31.9 \\
Missing & 3 & & 3 & 0.8 \\
TOTAL & $\mathbf{2 5 8}$ & $\mathbf{1 2 1}$ & $\mathbf{3 7 9}$ & $\mathbf{1 0 0}$ \\
\hline Age & & & & \\
$50-54$ & 119 & 61 & 180 & 47.5 \\
$55-59$ & 85 & 40 & 125 & 33.2 \\
60-64 & 39 & 16 & 55 & 14.7 \\
65-69 & 11 & 3 & 14 & 3.7 \\
$70-74$ & 1 & 0 & 1 & 0.3 \\
Missing & 3 & 1 & 4 & 0.8 \\
TOTAL & $\mathbf{2 5 8}$ & $\mathbf{1 2 1}$ & $\mathbf{3 7 9}$ & $\mathbf{1 0 0 . 2}$ \\
\hline & & & & \\
Current Employment & & & & \\
Permanent full-time & 236 & 81 & 317 & 84.2 \\
Permanent part-time & 3 & 15 & 18 & 4.7 \\
Fixed term FT & 8 & 10 & 18 & 5.0 \\
Fixed term PT & 1 & 0 & 1 & 0.3 \\
Contractor & 1 & 2 & 3 & 0.8 \\
Missing & 4 & 1 & 5 & 0.5 \\
TOTAL & $\mathbf{2 5 8}$ & $\mathbf{1 2 1}$ & $\mathbf{3 7 9}$ & $\mathbf{1 0 0}$ \\
\hline
\end{tabular}

Other demographic information relates to the type of job held by respondents, including Clerical/customer service (27.4\%), Professional (15\%), Technical (13.5\%), Management (12.7\%), Construction/Labourers and related workers (9.8\%), Operational/Transport workers (7.9\%), Tradesperson/trades assistant (6.9\%) and other (3.7\%), with 12 non-responses (see Table 4).

Table 4

Type of job

\begin{tabular}{|l|c|c|c|c|}
\hline & Males & Females & $\begin{array}{c}\text { Employees } \\
\text { (N = 379) }\end{array}$ & $\begin{array}{c}\text { Percent } \\
\text { (\%) }\end{array}$ \\
\hline Type of job & & & & \\
Professional & 34 & 23 & 57 & 15 \\
Management & 38 & 9 & 47 & 12.7 \\
Tradesperson/trades asst & 26 & 0 & 26 & 6.9 \\
Clerical/customer service & 24 & 80 & 104 & 27.4 \\
Operational/transport & 28 & 1 & 29 & 7.9 \\
Construction/labourer & 35 & 2 & 37 & 9.8 \\
Technical & 47 & 4 & 51 & 13.5
\end{tabular}


Other

Missing

TOTAL

\subsection{Quantitative Analysis}

Table 5 details the means, standard deviations, and correlation coefficients amongst the variables and the alpha reliability coefficients for each variable. The findings indicate that the intention to continue working is significantly related to several dependent variables: the importance of working to the individual, perception of autonomy at work, flexibility at work, management and organisational factors, and interests outside of work. However, future working intentions are not significantly related to attachment to work, interpersonal relationships at work or the control variable (work area: that part of the organisation in which the employee works). Overall, the range of means suggests that respondents at least "agreed" (with a minimum mean of over 4 out of 7 ) that most of the variables would likely influence their intentions to continue paid work. However, the mean for management and organisational factors $(m=5.32)$, the highest mean of all variables, suggests that older workers at least moderately agreed that such factors do affect their intentions to continue working. In contrast, respondents at least slightly disagreed that the importance of work affects their intentions to continue working $(\mathrm{m}=2.69)$.

Table 5

Means, Standard Deviations and Correlations ${ }^{\mathrm{a}}$ - Information related to variables

\begin{tabular}{|c|c|c|c|c|c|c|c|c|c|c|c|c|}
\hline Variable & $\mathbf{M}$ & SD & $\begin{array}{c}\text { Chronbach' } \\
\text { s Alpha } \\
\end{array}$ & 1 & 2 & 3 & 4 & 5 & 6 & 7 & 8 & 9 \\
\hline $\begin{array}{l}\text { 1. Attachment } \\
\text { to work }\end{array}$ & 4.15 & 1.34 & .76 & 1 & $.30^{* *}$ & $.31^{* *}$ & .10 & $.16^{* *}$ & -.03 & .09 & .01 & -.06 \\
\hline 2. Import work & 2.69 & 1.35 & .69 & $.30 * *$ & 1 & $33^{* *}$ & .07 & -.04 & -.06 & -.08 & $.205^{* *}$ & -.09 \\
\hline $\begin{array}{l}\text { 3. Interpersonal } \\
\text { relationships }\end{array}$ & 3.79 & 1.25 & .811 & $.31^{* *}$ & $.33 * *$ & 1 & $.34^{* *}$ & $.23^{* *}$ & $.24^{* *}$ & $.15^{* *}$ & .08 & -.06 \\
\hline 4. Autonomy & 4.83 & 1.43 & .869 & .10 & .07 & $.34 * *$ & 1 & $.30 * *$ & $.53 * *$ & $.28^{* *}$ & $.22 * *$ & -.03 \\
\hline 5. Flexibility & 4.82 & 1.84 & .89 & $.16^{* *}$ & -.04 & $.23^{* *}$ & $.3 * *$ & 1 & $.34 * *$ & $.38 * *$ & $.34 * *$ & -.06 \\
\hline $\begin{array}{l}\text { 6. Management } \\
\text { \& organisation }\end{array}$ & 5.32 & 1.56 & .76 & -.03 & -.06 & $.24 *$ & $.53^{* *}$ & $.34 * *$ & 1 & $.38 * *$ & $.30 * *$ & .04 \\
\hline $\begin{array}{l}\text { 7. Interests } \\
\text { outside work }\end{array}$ & 3.45 & 1.37 & .85 & .09 & -.08 & $.15^{*}$ & $.28^{* *}$ & $.38 * *$ & .38 & 1 & $.49 * *$ & -.03 \\
\hline 8. Future work & 4.45 & 1.27 & & .01 & $.205^{* *}$ & .078 & $.216^{* *}$ & $.339 * *$ & $.303^{* *}$ & $.492 * *$ & 1 & -.03 \\
\hline $\begin{array}{l}\text { 9. Work Area } \\
\text { (control) }\end{array}$ & & & & -.06 & -.09 & -.056 & -.03 & -.005 & .04 & .03 & -.03 & 1 \\
\hline
\end{tabular}


${ }^{\text {a }} \mathrm{N}=379$. Numbers in parentheses on the diagonal are the Cronbach's alpha coefficients of the composite scales.

**. Correlation is significant at the 0.01 level (2-tailed).

*. Correlation is significant at the 0.05 level (2-tailed)

Hypothesis 1. In order to address the first hypothesis, a regression analysis was undertaken. There was a positive relationship between 'attachment to work for the individual' and 'older workers' intentions to continue working' (beta=.14, $\mathrm{p}<.001$ ), hence hypothesis 1 was supported (see Table 6).

Hypothesis 2. In order to address the second hypothesis, a regression analysis was undertaken. There was a positive relationship between 'Importance of work to the individual' and 'older workers' intentions to continue working' (beta $=.329, \mathrm{p}<.001$ ), hence hypothesis 2 was supported (see Table 6).

Hypothesis 3. In order to address the third hypothesis, a regression analysis was undertaken. There was a positive relationship between 'interpersonal relationships' and 'older workers' intentions to continue working' (beta $=.264, \mathrm{p}<.001$ ), hence hypothesis 3 was supported (see Table 6).

Hypothesis 4. In order to address the fourth hypothesis, a regression analysis was undertaken. There was no significant relationship between "perceptions of autonomy" and “older workers' intentions to continue working” because the beta score was not significant (beta $=.009$ ). Hence, hypothesis 4 was rejected (see Table 6).

Hypothesis 5. In order to address the fifth hypothesis, a regression analysis was undertaken. There was no significant relationship between "flexible working arrangements" and "older workers' intentions to continue working" because the beta score was not significant (beta $=.045$ ). Hence, hypothesis 5 was rejected (see Table 6).

Hypothesis 6. In order to address the sixth hypothesis, a regression analysis was completed. There was a positive relationship between 'interests outside of work' and 'older 
workers' intentions to continue working' (beta=.177, $\mathrm{p}<.005$ ), hence hypothesis 6 was supported (see Table 6).

Hypothesis 7. In order to address the seventh hypothesis, a regression analysis was undertaken. There was a negative relationship between poor 'management and organisational factors' and 'older workers' intentions to continue working' (beta=.177, $\mathrm{p}<.001$ ), hence hypothesis 7 was supported (see Table 6).

Notably, interests outside of work alone accounted for approximately $24.2 \%$ of the variance of older workers' intentions to continue working. A further $11.5 \%$ was explained by flexible work arrangements as a sole factor, while management and organisation factors accounted for an additional 9.2\%. That is, the variance of older workers' intentions to continue working is impacted upon differently by the various factors (see Table 6).

Table 6

Results from main effects regression analysis on employees' intentions to continue paid work

\begin{tabular}{|c|c|c|c|c|c|c|c|}
\hline $\begin{array}{l}\text { Independent } \\
\text { variables } \\
\text { Scale of } 1=\text { Strongly } \\
\text { Disagree, to } \\
\text { 7=Strongly Agree }\end{array}$ & $\begin{array}{l}\text { Dependent } \\
\text { Variable } \\
\text { Beta score }\end{array}$ & $\begin{array}{l}\text { Dependent } \\
\text { Variable } \\
\text { Beta score }\end{array}$ & $\begin{array}{l}\text { Dependent } \\
\text { Variable } \\
\text { Beta score }\end{array}$ & $\begin{array}{l}\text { Dependent } \\
\text { Variable } \\
\text { Beta score }\end{array}$ & $\begin{array}{l}\text { Dependent } \\
\text { Variable } \\
\text { Beta score }\end{array}$ & $\begin{array}{l}\text { Dependent } \\
\text { Variable } \\
\text { Beta score }\end{array}$ & $\begin{array}{l}\text { Dependent } \\
\text { Variable } \\
\text { Beta score }\end{array}$ \\
\hline $\begin{array}{l}\text { Attachment to } \\
\text { work }\end{array}$ & $.136 * *$ & & & & & & \\
\hline $\begin{array}{l}\text { Importance of } \\
\text { Work }\end{array}$ & & $.329 * *$ & & & & & \\
\hline $\begin{array}{l}\text { Interpersonal } \\
\text { relationships }\end{array}$ & & & $.264 * *$ & & & & \\
\hline Autonomy & & & & .009 & & & \\
\hline Flexibility of Work & & & & & -.045 & & \\
\hline $\begin{array}{l}\text { Interests outside } \\
\text { work }\end{array}$ & & & & & & $-.177^{*}$ & \\
\hline $\begin{array}{l}\text { Management and } \\
\text { organisation }\end{array}$ & & & & & & & $-.158 * *$ \\
\hline $\mathbf{R}^{2}$ & $1.6 \%$ & $10.8 \%$ & $7 \%$ & $.23 \%$ & $.3 \%$ & $3.1 \%$ & $2.5 \%$ \\
\hline $\mathbf{F}$ & 6.88* & $44.359 * *$ & $26.889 * *$ & 0.3 & 0.74 & $11.935^{* *}$ & $9.20 * *$ \\
\hline
\end{tabular}

* Significant at the 0.01 level (2-tailed).

* Significant at the 0.05 level (2-tailed)

In order to calculate the impact of multiple factors, a multiple regression must be conducted. Multiple regression analysis identified that the combined four factors of importance of working to the individual, flexible working arrangements, interests outside of 
work, plus management and organisational factors accounted for approximately $31.2 \%$ of the variance of older workers' intentions to continue working. This means that these four workrelated factors are important to older workers because they significantly affect their intentions to continue working (see Table 7). However, the effect of the individual variables differs

Table 7

Multiple regression analysis: Relationship between 7 variables and older workers' intentions to continue paid work

\begin{tabular}{|c|c|}
\hline Independent Variables & $\begin{array}{c}\text { Employees' intentions to continue paid } \\
\text { work }(\beta)\end{array}$ \\
\hline Attachment to work & .003 \\
\hline Importance of work & $.142 *$ \\
\hline Interpersonal relationships & -.011 \\
\hline Perception of autonomy & .035 \\
\hline Flexible work arrangements & $.12 *$ \\
\hline $\begin{array}{l}\text { Perception of management and } \\
\text { organisational factors }\end{array}$ & $.098 *$ \\
\hline Interests outside of work & $.407 * *$ \\
\hline $\mathbf{F}$ & $21.882 * *$ \\
\hline $\mathbf{R}^{2}$ & .312 \\
\hline $\mathbf{N}$ & 379 \\
\hline
\end{tabular}

** Significant at the 0.01 level (2-tailed).

* Significant at the 0.05 level (2-tailed)

When other factors were controlled, four factors (importance of working to the individual, flexible working arrangements, interests outside of work, plus management and organisational factors) were significant predictors of older workers' intentions to continue working. Notably, the perception of autonomy was individually significant as a predictor of the intention to continue working. However, when combined with other factors, it was found to be not significant. One explanation for this may be that the impact of perceptions of autonomy is camouflaged by flexible work arrangements and/or management and organisational factors, which may determine older workers’ perceptions of autonomy. There 
is therefore a need to undertake future research to reduce any multicolinearity between the variables so that interaction effects do not camouflage the impact of any variable, such as the perception of autonomy.

\section{Discussion}

The contribution of this paper is that it has extended parts of the MOW model by Westwood and Lok (2003) to specifically focus on older workers, by arguing that OWICW not only is a function of factors previously tested (health and financial factors), but also is a function of four work-related variables - the importance of working to the individual, the flexibility of working arrangements, the individual's interests outside of work, plus management and organisational factors (such as supervision, bureaucracy and the work environment). The first process involved reviewing relevant literature to identify the work-related factors likely to significantly affect older workers' intentions to continue working. The second step involved reviewing and identifying validated scales to test the proposed work-related factors. In some cases, validated scales could be found and in those cases, a review of relevant literature informed the development of statements used to test the variable. The reliability of the scales involved using a pilot survey as a means of modifying the scales used to test the work-related measures. The final stage involved undertaking factor analysis of all variables to establish validity of the proposed model. The outcome is a conceptual model with validated measures showing that several work-related factors - importance of work, flexible work arrangements, interests outside of work, plus management and organisational factors - offer a better understanding of the impact of work-related factors upon older workers' intentions to continue working (see Figure 2). As such, the findings support previous research conducted by Shacklock (2006; 2008) and Shacklock, Brunetto and Nelson (2009) that identified the importance of work-related factors as influences on an older individual's future working 
intentions. Thus, the identification and validation of these new factors adds to the emerging body of literature about older workers’ intentions to continue working.

[Insert Figure 2 about here]

As a result of this analysis, the 'black box' that once represented our understanding of the impact of work-related factors upon older workers' intentions to continue working has been somewhat illuminated. In particular, the findings have identified, operationalised and tested numerous work-related factors that fall within the domains entitled the 'subjective expectations about future working situations', including the importance of work to the individual, flexible work arrangements, management and organisational factors, and interests outside of work.

This study has a number of limitations. Firstly, the study is limited to a single large public sector organisation located in Queensland. This study thus needs to be replicated to test the validity of the findings in different organisational contexts, for example in small and medium enterprises and in the private sector. A second limitation relates to common methods bias in relation to the self-reporting techniques used to gather information in the survey that was used as one way of collecting the data. However, Spector (1994) argues that self reporting methodology is useful in providing trends that in turn provide understanding about older workers' feelings and perceptions, as long as the literature review and other evidence support the inferences and interpretations made about the data. Self-report methodology is only appropriate to use when it suits the research methodology, otherwise Spector (1994) argues the generalisations become too speculative. Self-reporting was the ideal way to explore older workers’ intentions to continue working - by asking them directly.

\section{Conclusion}

This paper extends the Meaning of Work model to explain the impact of work-related factors upon the intentions of older workers to continue in employment, and at the individual 
level of analysis. The findings from this paper thereby add to the MOW literature by extending and testing the MOW model and identifying the work-related factors that specifically influence older workers' intentions to continue in paid work. The previous MOW model was not specific to older workers and was limited in the 'consequences' of the meaning of working by not being sufficiently explanatory of older workers' intentions to continue working. The findings from this paper have contributed to the MOW literature by confirming that the consequences of the 'subjective expectations about future working situations' in the earlier MOW models were insufficient to determine an older individual's intention to continue working. This paper has therefore extended the MOW model by making transparent one consequence and by identifying work-related factors within 'subjective expectations about future working situations' that influence older workers' intentions to continue in employment. As a result, there is now a clear picture about the impact of work-related factors upon the meanings of working to older workers, and therefore upon their intentions to continue working.

The implications of these findings include providing a framework to begin addressing the challenge of retaining valued older workers so as to attend to the growing shortage of labour across OECD countries. Management has traditionally shunned older workers because of the perception of the abundance and better performance of younger workers. However, new evidence identifies that skilled labour is a valuable commodity in short supply and therefore the old perceptions, values and beliefs (and in turn the strategies, policies and practices of organisations that supported those perceptions) are no longer relevant. Organisations that ignore their significant part in affecting older workers' intentions to continue working will be strategically misaligned in their practices within a competitive labour market, and such decisions may affect their competitive advantage. The 'just-in-time’ reactive management of older workers no longer services the people needs of organisations, and better and longer-term HRM planning is required for the retention of valued older 
workers. Only those organisations incorporating changes to their strategic human resource plans, especially including work-related policies aimed at encouraging older workers to continue working, will be equipped to operate effectively within a contemporary labour market.

Organisations, human resource management and policy makers are now aware, from these findings, that they can impact the retention of valued older workers. With this new knowledge, organisations can now target valued older workers and potentially improve their retention rates by ensuring that working arrangements are sufficiently flexible to cater for their interests outside of work that they do not need to leave work in order to undertake their interests. Moreover, the importance of working is a clear reason for older workers to remain working and managers need to ensure that older workers are therefore provided with lots of opportunities for personal development. By enhancing the importance of working in older workers' lives, the research suggests that their intentions to continue working will be enhanced. Additionally, while organisations may have little control over an individual's interests outside of work, they need to consider improved options for addressing the significance to older workers of their outside interests - perhaps by providing greater flexibility in work arrangements. Moreover, the level of bureaucracy that older workers contend with must be better managed by organisations, so that it does not become a reason for valued older workers to leave work, because we now know it negatively impacts upon their intentions to continue working. Finally, it is clear that management and supervision continue to play a large part in older people’s working lives, and hence organisations need to continue targeting and training those best suited for such roles, in the new knowledge that such actions will influence the intentions of valued older workers to remain with them. These changes clearly aim to reduce early retirement and other attrition rates, and to raise the retention rates of valued older workers. The next step, to advance the debate within the HRM context, is an important area of future research. 


\section{REFERENCES}

AARP. (2007). International profit from experience. Washington, D. C.: AARP.

American Association of Retired Persons. (2005). The aging American worker - get ready. Washington, D. C.: American Association of Retired Persons.

Anderson, D., Johnson, D. and Saha, L. (2002) 'Changes in academic work: Implications for universities of the changing age distribution and work roles of academic staff'. Australian National University, Canberra

Arrowsmith, J. and McGoldrick, A. E. (1997) 'A flexible future for older workers?' Personnel Review, Vol.26, No. 4, pp. 258-273.

Australian Bureau of Statistics. (2006). Retirement and retirement intentions. Canberra: Australian Bureau of Statistics.

Barnes, H., and Parry, H. (2003). 'Renegotiating identity and relationships: Men and women's adjustment to retirement. Policy Studies Institute, Research Discussion Paper 14. London: PSI.

Barnes, H., Parry, J., and Taylor, R. (2004). Working after State Pension Age: Qualitative research. London: Department of Work and Pensions.

Blekesaune, M., and Solem, P. E. 2005, 'Working conditions and early retirement: A prospective study of retirement behavior'. Research on Aging, 27(1), pp. 3-30.

Branine, M. and Glover, I. (1997). 'Ageism in work and employment: thinking about connections', Personnel Review, Vol.26, No. 4, pp. 274-292.

Choo, T. E. (1999). 'The aging workforce: Some implications, strategies and policy considerations for human resource managers'. Asia Pacific Journal of Human Resources, Vol. 37 No. 2, pp. 60-75.

De Jonge, J. 1995, 'Job autonomy in the workplace, well-being, and health: A study among Dutch health care workers', Universitaire Pers Maastricht, Maastricht.

Department of the Treasury. (2004a). Australia's Demographic Challenges. Canberra: Department of the Treasury.

Department of the Treasury. (2004b). A more flexible and adaptable retirement income system. Canberra: Department of the Treasury.

Drucker, P. 2001 'A survey of the near future', The Economist, pp. 3-22.

Encel, S., and Studencki, H. (2004). Older workers: Can they succeed in the job market? Australasian Journal on Ageing, 23(1), 33-37.

England, G. W. (1991). The meaning of work in the USA: Recent changes. European Work and Organizational Psychologist, Vol. 1 No. 2/3, pp. 111-124.

Evandrou, M., and Glaser, K. (2004). 'Family, work and quality of life: Changing economic and social roles through the life course'. Ageing and Society, Vol. 24, pp. 771-791.

Friedmann, E. A., and Havighurst, R. J. (1977). The meaning of work and retirement. New York: Arno Press.

Gallie, D., and White, M. (1993). Employee commitment and the skills revolution. London: Policy Studies Institute.

Ginn, J., and Arber, S. (2005). 'Longer working: Imposition or opportunity? Midlife attitudes to work across the 1990s'. Quality in Ageing, Vol. 6, pp. 26-35.

Glover, I. and Branine, M. (1997). 'Ageism and the labour process: towards a research agenda', Personnel Review, Vol.26 No. 4, pp. 274-292.

Hansson, R. O., DeKoekkoek, P. D., Neece, W. M., and Patterson, D. W. (1997). 'Successful aging at work: Annual Review, 1992-1996: The older worker and transitions to retirement'. Journal of Vocational Behavior, Vol. 51, pp. 202-233.

Harpaz, I. (1999). Work values in Israel: Stability and change over time. Monthly Labour Review, Vol. 122, pp. 46-50. 
Humphrey, A., Costigan, P., Pickering, K., Stratford, N., and Barnes, M. (2003). Factors affecting the labour market participation of older workers. London: Department of Work and Pensions.

Jackson, N., Walter, M., Felmingham, B. and Spinaze, A. (2006) 'Will older workers change their retirement plans in line with government thinking? A review of recent literature on retirement intentions', Australian Labour Bulletin, Vol. 32 No. 4, pp. 315-344.

Laslett, P. (1989). A fresh map of life. London: Weidenfeld and Nicholson.

Lee, T. W., and Mitchell, T. R. (1994). An alternative approach: The unfolding model of voluntary employee turnover. Academy of Management Review, Vol. 19, pp. 51-89.

Loretto, W., Vickerstaff, S., and White, P. (2005). Older workers and options for flexible work. Manchester: Equal Opportunities Commission.

Lyon, P. and Pollard, D. (1997). 'Perceptions of the older employee: is anything really changing?' Personnel Review, Vol.26, No. 4, pp. 245-257.

Meaning of Working International Research Team (1987). The meaning of working, Academic Press, London.

Nunnally, J.C. (1978). Psychometric theory, 2nd edition. New York: McGraw-Hill.

OECD. (2003). Maintaining a prosperous society: Ageing research report: Organisation for Economic Co-operation and Development.

Patrickson, M., and Ranzijn, R. (2004). 'Bounded choices in work and retirement in Australia’. Employee Relations, Vol. 26 No. 4, pp. 422-432.

Phillipson, C. (2004). 'Work and retirement transitions: Changing sociological and social policy contexts'. Social Policy and Society, Vol. 3 No. 2, pp. 155-162.

Phillipson, C., and Smith, A. (2005). Extending working life: A review of the research literature (No. 299). Norwich, UK: Department for Work and Pensions.

Platman, K. (2004). 'Flexible employment in later life: Public policy panaceas in the search for mechanisms to extend working lives'. Social Policy and Society, Vol. 3 No. 2, pp. 181-188.

Probert, B., and MacDonald, F. (1996). The work generation: The future of work. Melbourne: Brotherhood of St Laurence.

Productivity Commission. (2005). Economic implications of an ageing Australia: Research report. Canberra: Australian Government Productivity Commission.

Productivity Commission (2006) 'Workforce participation rates - How does Australia compare?' Staff Working Paper. Australian Government Productivity Commission, Canberra

Rubin, R. B., Perse, E. M., and Barbato, C. A. (1988). 'Conceptualization and measurement of interpersonal communication motives’. Communication Quarterly, Vol. 40, pp. 305-317.

Schramm, J. (2006). SHRM Workplace forecast. Alexandria, VA: Society of Human Resource Management.

Shacklock, K. (2006). 'Extended working lives? The meaning of working to older university workers in Australia', International Journal of Human Resources Development and Management, Vol. 6 No. 2-4, pp. 161-173.

Shacklock, K. H. (2008). Shall I stay?: The meaning of working to older workers. Saarbrucken, Germany: VDM Verlag Dr Muller.

Shacklock, K. and Brunetto, Y. (2005) 'Employees' perceptions of factors affecting their decision to retire', International Journal of Organisational Behaviour, Vol. 10 No. 5, pp. 740-756.

Shacklock, K., Fulop, L. and Hort, L (2007). 'Managing older worker exit and re-entry practices - a “revolving door”?’ Asia Pacific Journal of Human Resources, Vol. 45 No. 2, pp. 151-167. 
Shacklock, K. H., Brunetto, Y., and Nelson, S. (2009). The different variables that affect older males' and females' intentions to continue working. Asia Pacific Journal of Human Resources, 47(1), 79-101.

Sheen, V. (1999). 'Older Australians: Working for the future' (Strategic ageing: Australian issues in ageing Vol 9/99). Melbourne: Council on the Ageing.

Smeaton, D., and McKay, S. (2003). Working after State Pension Age: Quantitative analysis. London: Department of Work and Pensions.

Westwood, R., and Leung, S. M. (1996). Working under the reforms: the experience and meaning of work in a time of transition. In M. Brosseau and S. Pepper and S-k. Tsang (Eds.), China Review (pp. 367-424). Hong Kong: Chinese University Press.

Westwood, R., and Lok, P. (2003). The meaning of work in Chinese contexts: A comparative study. International Journal of Cross Cultural Management, Vol. 3 No. 2, pp. 139165.

Yin, R. K. (1994). Case study research: Design and methods. Thousand Oaks, CA: Sage Publications. 


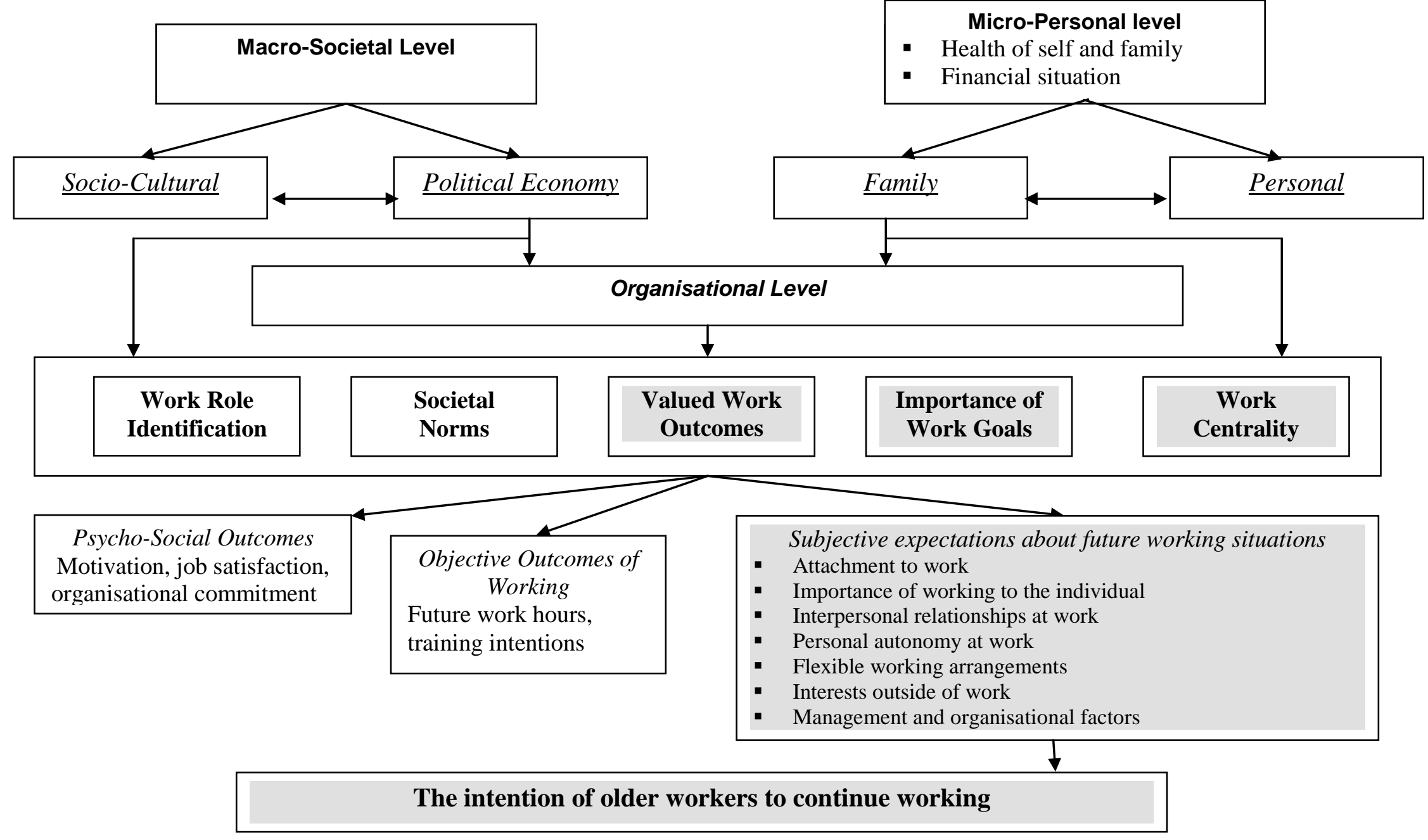

Figure 1: Model (adapted from Westwood and Lok, 2003) with highlighted variables used in this research 


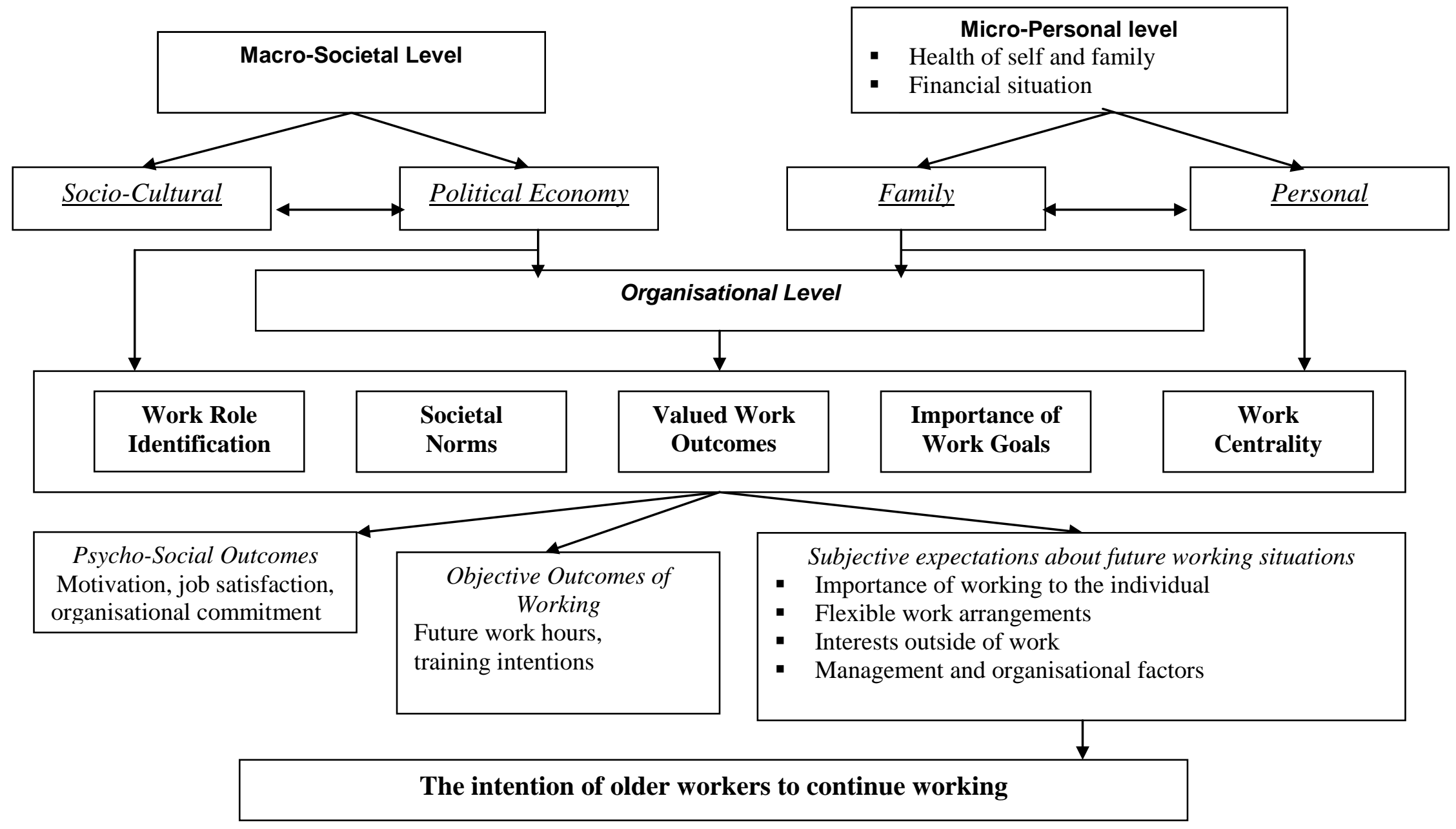

Figure 2: Revised model (adapted from Westwood and Lok, 2003) of the meaning of working to older workers and their intentions to continue in employment 